JEL код: R11

\title{
АГЛОМЕРАЦИЯ КАК ОБЪЕКТ ГОСУДАРСТВЕННОГО РЕГУЛИРОВАНИЯ
}

\author{
(C) 2020 Аширбекова Лаура Жалгасовна \\ кандидат экономических наук, старший преподаватель \\ Казахский национальный университет имени аль-Фараби, Казахстан, Алматы \\ Email: turar200480@mail.ru \\ (c) 2020 Ғалымқызы Гүлмира \\ докторант 1-го курса по специальности «Государственное и местное управление» \\ Казахский национальный университет имени аль-Фараби, Казахстан, Алматы \\ Email:gumka_1993@mail.ru
}

Данная статья посвящена анализу важного процесса современного социально-экономического развития городских агломераций. В развитых странах мира городские агломерации занимают значимое место для решения социально-экономических проблем.

Актуальность исследования определяется тем, что в настоящее время половина населения земного шара живут в городах и благодаря тому, что люди выбирают удобную и комфортную жизнь в городах ежегодно расширяются списки миллонных городов по всему миру.

В исследовании приводится рейтинг стран мира по уровню урбанизации, анализируются особенности урбанизации и государственного регулирования этого процесса.

Ключевые слова: городские агломерации, мегаполис, управление городскими агломерациями, урбанизация.

\section{Введение.}

Одним из наиболее важных процессов современного пространственного развития являеется урбанизация, приводящая к постепенному формированию крупных современных агломераций, отличающихся комплексным развитием хозяйства, увеличением лоли наукоемкого сектора и высокотехнологичных производств обрабатывающей промышленности, усилением межрегиональных экономических связей. В современном мире агломерации получили большое распространение, их развитие в полной мере может объясняться теорией «центральных мест» В. Кристаллера.

Быстрый рост населения и его концентрация в городах стали важной тенденцией пространственного развития во многих странах мира во второй половине XX в. Эти процессы носили столь масштабный и всеобъемлющий характер, что стали называться «городской революцией». Если в развитых странах рост крупных городов сейчас практически прекратился, то в развивающихся странах он набирает обороты.

Агломерационный путь развития - это естественный этап урбанизации. К 2050 году (по мнению ООН) количество горожан вырастит в два раза и достигнет 6,4 млрд. человек. На сегодняшний день существуют более 900 агломераций с численностью населения более 1 млн. человек [1].

Городская агломерация является высокоразвитой пространственной формой интегрированных городов. Это происходит, когда отношения между городами переходят от конкуренции в основном к конкуренции и сотрудничеству. Города сильно интегрированы в городскую агломерацию, что делает агломерацию одним из важнейших носителей глобального экономического развития. Исследования городских агломераций увеличились в последние десятилетия. В исследовательском сообществе не достигнут консенсус относительно того, что такое городская агломерация, как разграничивается городская агломерация в географическом пространстве, каковы эффективные модели управления городской агломерацией и т.д.

Города являются центральными местами для капитала, труда и информации. Они давно привлекают внимание исследователей из широкого круга дисциплин. Развитие, пространственная эволюция и пространственная организация городских форм являются основными темами исследований в области 
урбанизации и человеческой географии. Исследования по пространственной кластеризации городов начались еще в 1920-х годах, и для описания этой конкретной городской пространственной организации использовались различные термины. Эти термины включают мегаполис, городскую агломерацию, городскую группу и городской кластер [2].

Городская агломерация представляет собой сочетание компактных и относительно высокоразвитых, взаимодополняющих городских и сельских районов. Он сгруппирован в одно или несколько городов-ядер и сочетается с многомерными интенсивными связями; эта область представляет собой пространство потенциальных и реальных взаимодействий, отражающих еженедельный жизненный цикл населения современных крупных городов и его спутников, агломераций.

При анализе основных признаков мы выделили показанные на рисунке 1.

Существует 2 направления формирования городских агломераций:

1. Городская агломерация является высшей стадией развития крупного центра (развитие агломерации «из города»): в своем развитии крупный город превращается в агломерацию, состоящую из «ядра» (города-центры) и периферии (окружающие спутники).

2. Формирование агломераций из различных территорий - на основе крупных ресурсных массивов и крупной тяжелой промышленности, также на основе территориальных групп горожан постепенно организуются экономические, научные, культурные и т.д. В результате формируется важный центр с развитыми услугами. Далее на этом основании город станет ядром агломерации [4].
Следовательно, управление городскими агломерациями, включает в себя следующие функции:

- организация,

- координация,

- регулирование,

- информационное и законодательное обеспечение,

- наличие обратной связи, позволяющее в случае необходимости скорректировать управляющее воздействие.

В опубликованном рейтинге стран мира по уровню урбанизации представлен список 195 стран и территорий мира, по состоянию на 2018 год. В мире имеются 5 стран с уровнем урбанизации в 100\% - Гонконг, Кувейт, Монако, Науру и Сингапур. В странах СНГ по уровню урбанизации лидирует Беларусь (78,6\%), Россия $(74,4 \%)$, Украина (69,4\%), Армения (63,1\%), Казахстан (57,4\%).

В таблице 1 приводится уровень урбанизаций городского населения в странах мира. Видно, что доля городского населения у стран разная.

Согласно прогнозам в ближайшие годы рост населения городов будет продолжаться, а сельское население с наименьшим превышением 3,4 миллиарда человек в первой половине 2020 года сократится. В результате наибольшая часть населения мира будут проживать в городах.

Казахстан согласно рейтингу на 103 позиции и число городского населения в Казахстане составляет $57,3 \%$ от общей численности населения. Данное положение вызывает необходимость управления социально-экономическим и демографическими процессами в быстро растущих городах. Города в Казахстане постепенно адаптируются к рыночным условиям, на их долю приходится значительная часть эконо-

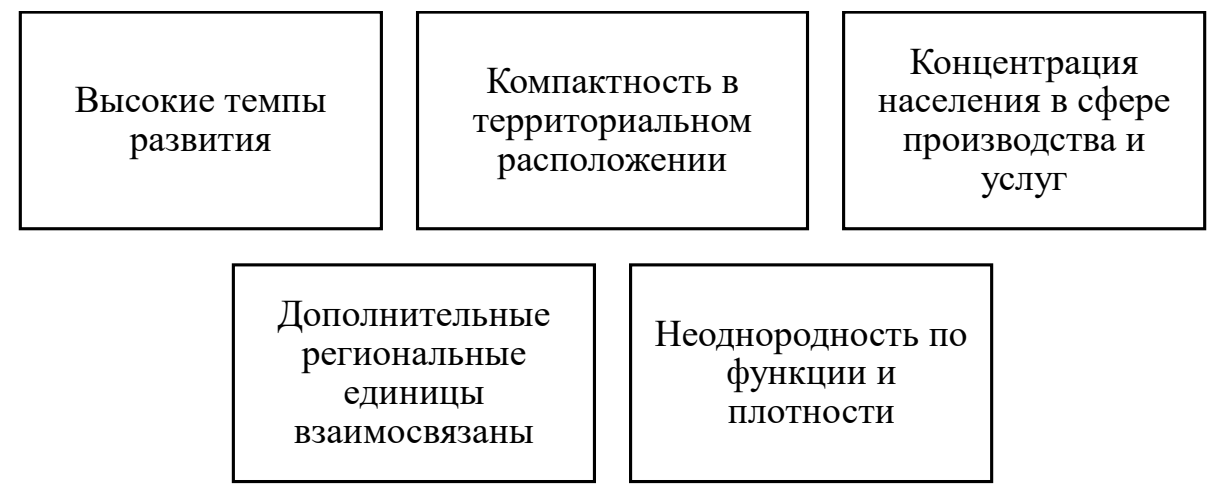

Рис. 1. Основные черты городской агломерации [4] 
Таблица 1. Рейтинг по уровню урбанизации

\begin{tabular}{|c|c|l|}
\hline № & Рейтинги & \multicolumn{1}{c|}{ Страны } \\
\hline 1 & $1-10$ & $\begin{array}{l}\text { Гонконг; Кувейт; Монако; Науру; Сингапур; Катар; Бельгия; Сан-Марино; Уругвай; } \\
\text { Мальта (городское население 95-100\%) }\end{array}$ \\
\hline 2 & $11-20$ & $\begin{array}{l}\text { Исландия; Израиль; Аргентина; Япония; Нидерланды; Иордания; Люксембург; Габон; } \\
\text { Бахрейн; Ливан (городское население 88-94\%) }\end{array}$ \\
\hline 3 & $21-30$ & $\begin{array}{l}\text { Венесуэла; Андорра; Дания; Чили; Швеция; Бразилия; Новая Зеландия; } \\
\text { Объединённые Арабские Эмираты; Австралия; Финляндия } \\
\text { (городское население 85-88\%) }\end{array}$ \\
\hline 4 & $31-40$ & $\begin{array}{l}\text { Оман; Саудовская Аравия; Великобритания; Багамские Острова; Соединённые Штаты } \\
\text { Америки; Норвегия; Южная Корея; Канада; } \\
\text { Доминикана; Колумбия (городское население 80-84\%) }\end{array}$ \\
\hline 5 & $41-50$ & $\begin{array}{l}\text { Франция; Испания; Мексика; Ливия; Палау; Коста-Рика; Греция; Беларусь; Перу; } \\
\text { Джибути; (городское население 77-80) }\end{array}$ \\
\hline 6 & $101-110$ & $\begin{array}{l}\text { Австрия; Македония; Казахстан; Гондурас; Хорватия; Сейшельские Острова; } \\
\text { Камерун; Фиджи; Гана; Сербия (городское население 56-58\%) }\end{array}$ \\
\hline \multicolumn{2}{|l}{ Примечание: Рейтинг урбанизации стран мира [4] } \\
\hline
\end{tabular}

мической активности, в городах сконцентрирована созданная в стране рыночная инфраструктура.

Преимущества развитие городских агломерации:

- концентрация научного и экономического потенциала;

- улучшение качества жизни и культуры;

- эффективное использование трудовых ресурсов, увеличение рабочих мест, сокращение безработицы;

- рациональное использование потенциала и ресурсов экономико-географического положения территории [5].

Принципы развития агломерации:

- географическая целостность;

- экономическая целостность;

- встроенности в территорию страны;

- системный;

- защитный;

- динамичный;

- экономической самостоятельности.

Таким образом, перед органами государственной власти многих стран стоит непростой вопрос развития агломерации. Система государственного регулирования агломерационных процессов включает:

- правовое регулирования,

- экономическое регулирования,

- административное регулирования,
- градостроительное регулирования [6].

Стратегия повышения роли городских агломерации и городов получила название глокализации. В ее рамках основными задачами политики экономического развития городов становится привличение глобальных потоков капитала. Обеспечение этой цели достигается за счет специальных мер как на уровне государства, так ина уровне местных властных. Приоритеты пространственной политики смещаются социальных задач на реализацию крупномасштабных городских проектов, усиливающих привлекательность городов для инвесторов, девелоперских компаний, финансовых кругов, а также туристо.

Долгосрочное процветания города зависит от уровня развития инфраструктуры и промышленности. Это будет благоприятно влиять экономике города, на экономическое развитие и процветания города.

Подводя итоги можно выделить, что современные города становятся движущей силой развития в результате концентрации огромного человеческого, интеллектуального, технологического, финансового, экономического и других ресурсов.

В эпоху глобализации стремление выбора городской жизни половины человечества является доказательством интенсивного прогресса урбаназиции по всему миру. 


\section{Библиографический список}

1. Доклад «Мировые перспективы урбанизации пересмотренное издание 2014 года» на сайте OOH: http://esa. un.org/unpd/wup/ http://www.un.org/en/development/desa/publications/index.html

2. Chuanglin Fanga, Danlin Yub «Urban agglomeration: An evolving concept of an emerging phenomenon» Landscape and Urban Planning 162 (2017) 126-136 jour nal home page: www.elsevier.com/locate/landurbplan http://dx.doi. org/10.1016/j.landurbplan.2017.02.014 P.1

3. Lappo, G.M. «Purposeful formation of urban agglomerations.» [Celenapravlennoe formirovanie gorodskix aglomeraciy] Проблемы развития агломераций России, 2009, изд. Красанд: 192

4. The United Nations Department of Economic and Social Affairs: Urban Population Index 2018. Рейтинг урбанизации стран мира. Гуманитарная энциклопедия: Исследования [Электронный ресурс] // Центр гуманитарных технологий, (последняя редакция: 16.01.2020).URL: https:/gtmarket.ru/ratings/urbanization-index/info.

5. Ёлшина A.А. Городские агломерации: теоретические проблемы и анализ зарубежного опыта // Современные научные исследования и инновации. 2015. № 7. Ч.3 [Электронный ресурс]. URL: http://web.snauka.ru/ issues/2015/07/56419 (дата обращения: 25.03.2019).

6. Л.Я. Герцберг «Агломерации как объект экономической политики, государственного регулирования и территориального планирования» Градостроительство № 4, 2015 г С.101 